ARTICLE

https://doi.org/10.1038/s41467-019-10958-8

\title{
Structural basis of Q-dependent transcription antitermination
}

Jing Shi ${ }^{1}$, Xiang Gao ${ }^{1}$, Tongguan Tian¹, Zhaoyang Yu¹, Bo Gao ${ }^{1}$, Aijia Wen ${ }^{1}$, Linlin You ${ }^{2,3}$, Shenghai Chang ${ }^{4}$, Xing Zhang ${ }^{1,4}$, Yu Zhang (i) ${ }^{2} \&$ Yu Feng (D) ${ }^{1}$

Bacteriophage Q protein engages $\sigma$-dependent paused RNA polymerase (RNAP) by binding to a DNA site embedded in late gene promoter and renders RNAP resistant to termination signals. Here, we report a single-particle cryo-electron microscopy (cryo-EM) structure of an intact Q-engaged arrested complex. The structure reveals key interactions responsible for $\sigma$ dependent pause, $\mathrm{Q}$ engagement, and Q-mediated transcription antitermination. The structure shows that two $\mathrm{Q}$ protomers ( $\mathrm{Q}^{\prime}$ and $\left.\mathrm{Q}^{\prime \prime}\right)$ bind to a direct-repeat DNA site and contact distinct elements of the RNA exit channel. Notably, Ql forms a narrow ring inside the RNA exit channel and renders RNAP resistant to termination signals by prohibiting RNA hairpin formation in the RNA exit channel. Because the RNA exit channel is conserved among all multisubunit RNAPs, it is likely to serve as an important contact site for regulators that modify the elongation properties of RNAP in other organisms, as well.

\footnotetext{
${ }^{1}$ Department of Biophysics, and Department of Pathology of Sir Run Run Shaw Hospital, Zhejiang University School of Medicine, 310058 Hangzhou, China. ${ }^{2}$ Key Laboratory of Synthetic Biology, CAS Center for Excellence in Molecular Plant Sciences, Shanghai Institute of Plant Physiology and Ecology, Chinese Academy of Sciences, 200032 Shanghai, China. ${ }^{3}$ University of Chinese Academy of Sciences, 100049 Beijing, China. ${ }^{4}$ Center of Cryo Electron Microscopy, Zhejiang University School of Medicine, 310058 Hangzhou, China. Correspondence and requests for materials should be addressed to Y.F. (email: yufengjay@zju.edu.cn)
} 
$\mathrm{T}$ ranscription can be divided into three phases: initiation, elongation, and termination. To initiate transcription at a specific DNA sequence, promoter, bacterial RNA polymerase (RNAP) need to form holoenzyme with $\sigma$ factor. The principle $\sigma$ factor, $\sigma^{70}$ in Escherichia coli (E.coli), contacts RNAP extensively and mediates sequence-specific interactions with promoter $\mathrm{DNA}^{1-8}$. In particular, $\sigma$ conserved region $\sigma \mathrm{R} 2$ contacts a domain of $\beta^{\prime}$ subunit known as the clamp helices and mediates sequence-specific interactions with the promoter -10 element, while $\sigma$ conserved region $\sigma \mathrm{R} 4$ contacts the $\beta$ flap tip helix (FTH) and the $\beta^{\prime}$ dock, and mediates sequence-specific interaction with the promoter -35 element.

Bacteriophage Q protein has served as a paradigm for studying regulation of transcription elongation ${ }^{9}$. Through its engagement with RNAP, Q renders RNAP resistant to terminators. Q requires two cis-acting elements embedded within phage late gene promoter, $\mathrm{P}_{\mathrm{R}^{\prime}}$, to engage RNAP: a -10 -like sequence and a $\mathrm{Q}$ binding element $(\mathrm{QBE})$. The -10 -like sequence is located in the initial transcribed region, resembles the promoter -10 element, and mediates $\sigma$-dependent pause $e^{10-12}$. Q engages the paused RNAP when bound to the $\mathrm{QBE}$, which is located between the -35 element and -10 element of promoter $\mathrm{DNA}^{13}$. A successful recruitment to RNAP of bacteriophage $\lambda \mathrm{Q}$ protein $(\lambda \mathrm{Q})$ requires a third cis-acting element, the -35-like sequence, which is absent in the late gene promoters of other lambdoid phages ${ }^{14}$.

Genetic and biochemical studies have elucidated some aspects of Q-dependent antitermination ${ }^{9}$. Nevertheless, a precise mechanistic understanding of the process remains elusive, in part, because of a lack of structural information for Q-engaged complexes $^{15}$. The Q protein of bacteriophage 21 (21Q) was characterized as sharing a conserved mechanism of action with $\mathrm{Q}$ proteins from other lambdoid phages ${ }^{16}$. To investigate how $\mathrm{Q}$ renders RNAP resistant to terminators, and to visualize sequencespecific interaction of $\mathrm{Q}$ with $\mathrm{QBE}$, we determined a crystal structure of $21 \mathrm{Q}$ at $1.45 \AA$ resolution and a single-particle cryoelectron microscopy (cryo-EM) structure of an intact 21Qengaged arrested complex at $4.08 \AA$ resolution. The structures show that two 21Q protomers $\left(\mathrm{Q}^{\mathrm{I}}\right.$ and $\left.\mathrm{Q}^{\mathrm{II}}\right)$ bind to the directrepeat $\mathrm{QBE}$ site. The structures further reveal that $\mathrm{Q}^{\mathrm{I}}$ forms a ring-like structure inside the RNA exit channel, which only allows the passage of single-stranded RNA. Together, our results suggest that $\mathrm{Q}$ renders RNAP resistant to termination signals by prohibiting RNA hairpin formation in the RNA exit channel.

\section{Results}

21Q-dependent antitermination is boosted by GreB. Full length 21Q without any expression tag was purified as soluble protein. To ascertain the antitermination activity of purified $21 \mathrm{Q}$, we developed a transcription antitermination assay by taking advantage of an RNA fluorogenic aptamer, Mango $\mathrm{III}^{17}$. Specifically, a DNA fragment, consisting of bacteriophage 21 late gene promoter $\left(21 \mathrm{P}_{\mathrm{R}^{\prime}}\right)$ and terminator $\left(21 \mathrm{t}_{\mathrm{R}^{\prime}}\right)$ followed by Mango III encoding sequence, is transcribed in vitro (Fig. 1a). If RNAP reads through terminator $21 t_{R^{\prime}}$, Mango III encoding sequence is transcribed and the transcript becomes fluorescent when bound to TO1-Biotin. The fluorescence intensity in the presence of $21 \mathrm{Q}$ is $\sim 2$-fold higher than that in the absence of $21 \mathrm{Q}$ (Fig. 1b), indicating that purified $21 \mathrm{Q}$ improves the read-through of a

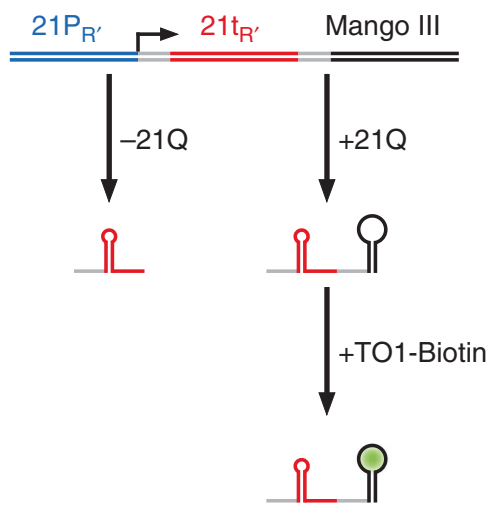

C

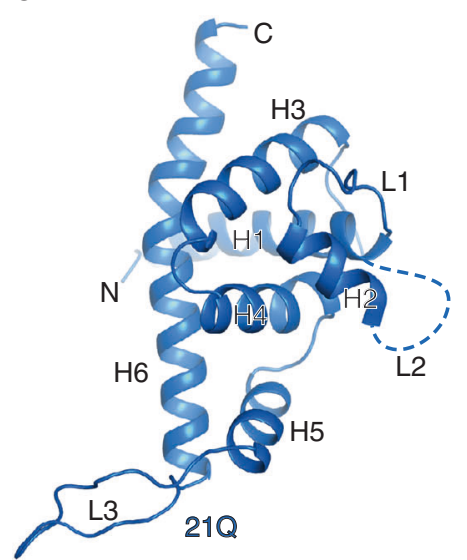

d

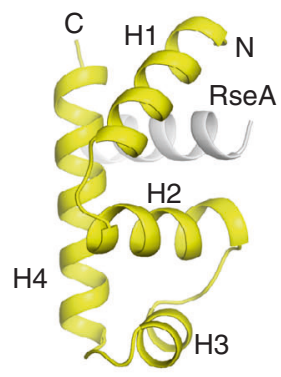

$\sigma R$

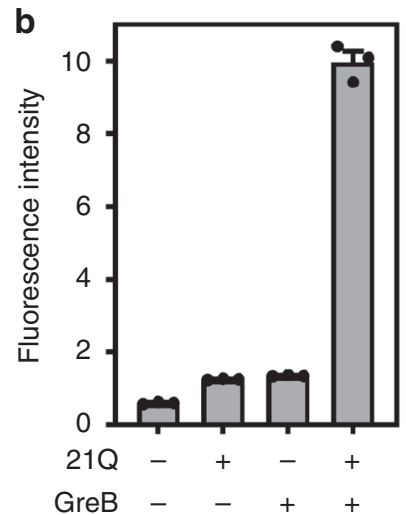

e

C

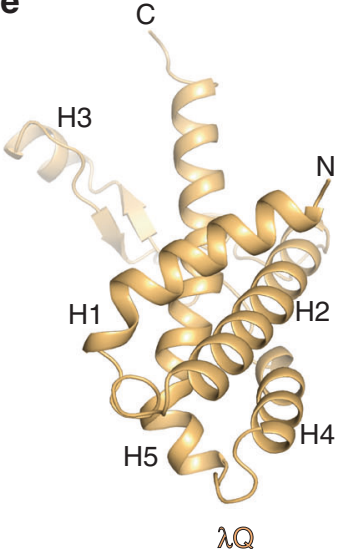

Fig. 1 Crystal structure of 21Q. a Principle of Mango III transcription antitermination assay. b 21Q-dependent antitermination is boosted by GreB (mean \pm SEM; 3 determinations). c Crystal structure of 21Q. The disordered region of L2 is denoted as a dashed loop. $\mathbf{d}$ Crystal structure of $\sigma R 4$ in complex with anti- $\sigma$ RseA (PDB 1OR7 [10.2210/pdb1OR7/pdb]). Yellow, $\sigma R 4$; gray, RseA. e Crystal structure of N-terminal truncated $\lambda Q$ (PDB 4MO1 https://doi.org/ $10.2210 / p d b 4 M 01 / p d b)$. Error bars represent mean \pm SEM out of $n=3$ experiments. Source data are provided as a Source Data file 
transcription termination signal by RNAP. If GreB is included in the reactions, the fluorescence intensity in the presence of $21 \mathrm{Q}$ is $\sim 10$-fold higher than that in the absence of $21 \mathrm{Q}$, which is in accordance with the previous reports that Q-dependent antitermination can be boosted by $\mathrm{GreB}^{9,18}$.

Crystal structure of 21Q. The crystal structure of 21Q was determined at $1.45 \AA$ resolution (Fig. 1c and Supplementary Table 1). The structure of 21Q contains six helices (H1-H6) and three long loops (L1-L3). A segment of L2 is disordered in the crystal structure, indicating the intrinsic flexibility of this region. Surprisingly, the structure of $21 \mathrm{Q}$ is reminiscent of the binary complex structure of $\sigma \mathrm{R} 4$ bound to anti- $\sigma$ RseA (Fig. 1c, d) ${ }^{19}$. Specifically, the folding of 21Q H3-H6 is similar to the folding of $\sigma \mathrm{R} 4$, while 21Q H1 binds to 21Q H3-H6 in the same way as RseA binds to $\sigma \mathrm{R} 4$. Because $\mathrm{H} 3$ and $\mathrm{H} 4$ of $\sigma \mathrm{R} 4$ form a helix-turn-helix (HTH) motif and participate in the binding and recognition of the -35 element $^{20}$, the corresponding helices of 21Q (H5 and H6) probably participate in the binding and recognition of the QBE. The crystal structure of $N$-terminal truncated $\lambda Q$ has been solved previously ${ }^{21}$. Similarly, H4 and H5 of $\lambda Q$ form a HTH motif (Fig. 1e). Other than that, there is no structural similarity between $21 \mathrm{Q}$ and $\lambda \mathrm{Q}$, which is consistent with the observation that although both $\mathrm{Q}$ proteins act by a similar mechanism, there is no obvious homology to their protein sequences ${ }^{16}$.

Cryo-EM structure of 21Q-engaged arrested complex. To obtain a bona fide 21Q-engaged complex, we first explored whether we could trap the complex through in vitro transcription. The in vitro transcription system included RNAP, 21Q, and a nucleic-acid scaffold corresponding to positions -45 to +34 of $21 P_{R}$, all C: $G$ base pairs of which between positions +1 and +20 were mutated to $\mathrm{G}: \mathrm{C}$ base pairs to prevent RNAP from running off the scaffold (positions numbered relative to the transcription start site; Fig. 2a and Supplementary Fig. 1A). As expected, de novo transcription using the scaffold yielded a 20 -nt RNA transcript in the absence of CTP (Supplementary Fig. 1B). Cleavage with GreB eliminated the 20-nt RNA transcript and yielded a 14nt cleavage product, indicating that RNAP is arrested in a backtracked state at position +14 . The result of GreB cleavage experiment is consistent with the previous report that Q-engaged

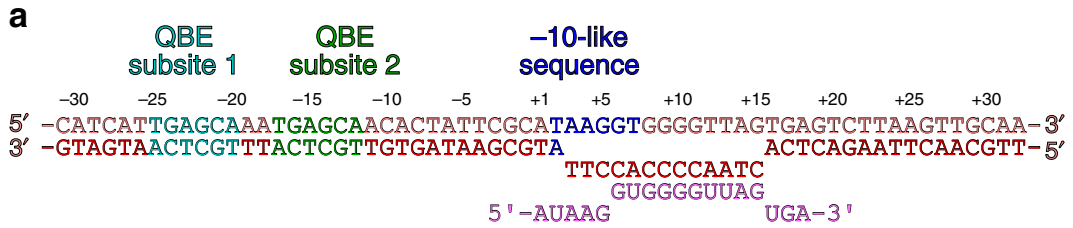

b
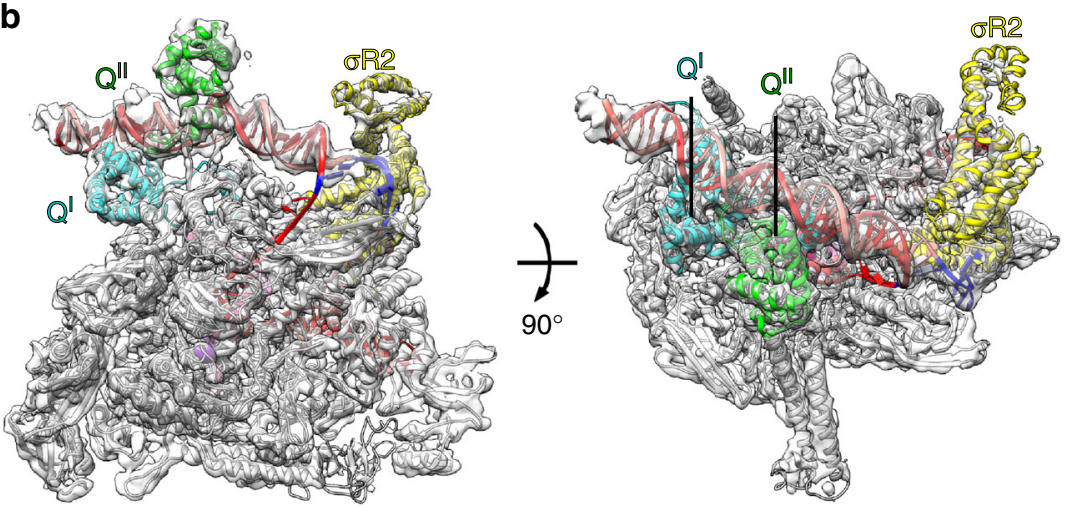

C
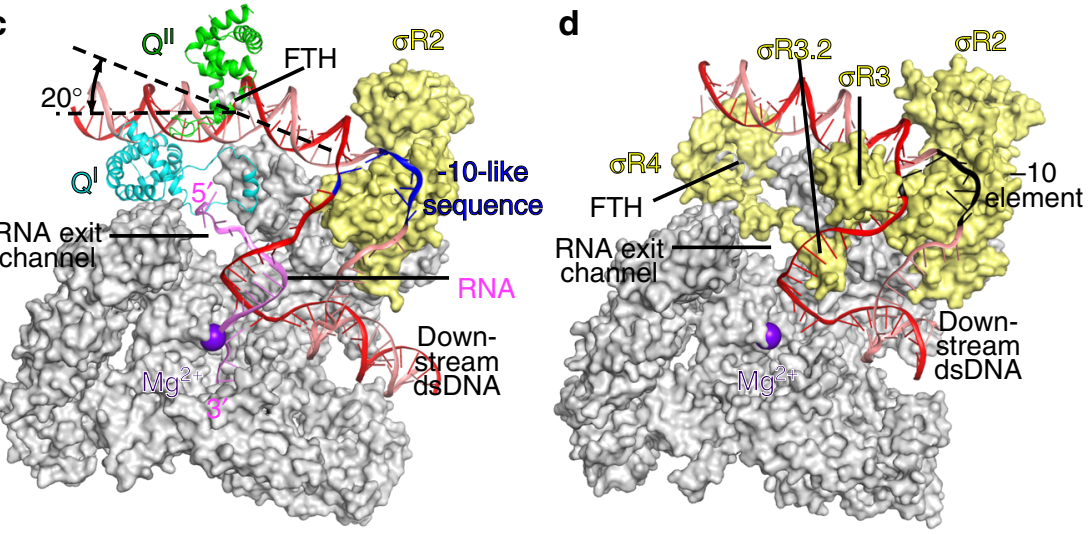

Fig. 2 Cryo-EM structure of 21Q-engaged arrested complex. a Nucleic-acid scaffold. Only ordered segment in the structure is shown. Salmon, nontemplate strand; red, template strand; pink, RNA; cyan, QBE subsite 1; green, QBE subsite 2; blue, -10-like sequence. Positions are numbered relative to the transcription start site. $\mathbf{b}$ The cryo-EM density map without B-factor sharpening and the superimposed model of 21Q-engaged arrested complex. Gray, RNAP; cyan, Q'; green, Qll; yellow, $\sigma^{70}$; violet, active center $\mathrm{Mg}^{2+}$; salmon, nontemplate strand; red, template strand; pink, RNA; blue, -10 -like sequence. c The model of 21Q-engaged arrested complex. RNAP and $\sigma^{70}$ are shown as surfaces. View orientation and colors as in the left subpanel of $\mathbf{b}$. $\beta$, except the FTH, is omitted for clarity. d The model of RPo (PDB 4YLN [10.2210/pdb4YLN/pdb]). View orientation and colors as in $\mathbf{c}$, except that the promoter -10 element is colored black 
RNAP is prone to backtrack to the site of $\sigma$-dependent pause where $Q$ initially engages ${ }^{18}$.

Using an analogous method, we prepared the 21Q-engaged arrested complex in the absence of GreB, froze the sample, collected data on Titan Krios, and determined the structure at a nominal resolution of $4.08 \AA$ (Fig. 2b, Supplementary Figs 2-4; Supplementary Table 2). Local resolution calculation indicates that the central core of the structure was determined to 3.4-4.0 resolution (Supplementary Fig. $3 \mathrm{C}$ ). The RNAP of the structure is very similar to the previously reported $E$. coli elongation complex structures $^{22}$, with root-mean-square deviation (RMSD) of $1.02 \AA$ (3000 Cas aligned).

Consistent with the result of GreB cleavage experiment, RNAP is arrested in a backtracked state at position +14 (Fig. $2 \mathrm{a}, \mathrm{c}$, and Supplementary Fig. 4A). Specifically, nucleic-acid scaffold from +3 to +15 is unwound and adopts the same conformation as the transcription bubble in RNAP-promoter open complex (RPo; Fig. $2 c, d)^{4-8}$. Nascent RNA from +6 to +15 forms a 10-bp RNADNA hybrid with the template-strand single-stranded DNA (ssDNA), while 5' 5-nt RNA threads into the RNA exit channel. Although GreB cleavage experiment indicates that 3' 5-nt RNA is in the secondary channel, only 3 -nt RNA is ordered in the structure probably due to weak interactions between the backtracked RNA and the secondary channel.

Protein-DNA interactions that mediate $\sigma$-dependent pause. The structure of 21Q-engaged arrested complex defines the protein-DNA interactions that mediate $\sigma$-dependent pause. $\sigma$ conserved region $\sigma \mathrm{R} 2$ interacts with the -10 -like sequence in the same way as it interacts with the promoter -10 element in RPo (Fig. $2 c, d)^{1-8}$, consistent with the fact that $\sigma \mathrm{R} 2$ is necessary for $\sigma$ dependent pause $\mathrm{e}^{23}$. $\sigma$ conserved regions $\sigma \mathrm{R} 3, \sigma \mathrm{R} 3.2$, and $\sigma \mathrm{R} 4$ are displaced from RNAP probably because of the steric clashes between $\sigma \mathrm{R} 3.2, \sigma \mathrm{R} 4$, and 5' end of nascent RNA, consistent with the fact that $\sigma \mathrm{R} 3, \sigma \mathrm{R} 3.2$, and $\sigma \mathrm{R} 4$ are dispensable for $\sigma$-dependent pause $^{23}$.

Two $21 Q$ protomers engage one RNAP. In the cryo-EM density map, there are two density features adjacent to QBE, which can be attributed to two $21 \mathrm{Q}$ protomers (Fig. 2b, c, Supplementary Fig. 4B, C). Protomers bound to the upstream subsite (subsite 1) and the downstream subsite (subsite 2), hereinafter are designated $\mathrm{Q}^{\mathrm{I}}$ and $\mathrm{Q}^{\mathrm{II}}$, respectively. $\mathrm{Q}^{\mathrm{I}}$ has a large conformational change of a short helix, $\mathrm{H} 2$, which is detached from the main portion of $\mathrm{Q}^{\mathrm{I}}$ and moves $30 \AA$ away from its original location (Supplementary Figs $4 \mathrm{~B}, 5)$. The loops $\mathrm{L} 1$ and $\mathrm{L} 2$ connecting $\mathrm{H} 2$ to the main portion of $\mathrm{Q}^{\mathrm{I}}$ also move along and form a ring-like structure with $\mathrm{H} 2$. Other than that, the rest of $\mathrm{Q}^{\mathrm{I}}$ is similar to the crystal structure of $21 \mathrm{Q}$, with RMSD of $0.659 \AA$ (119 Cas aligned). Compared with the crystal structure of $21 \mathrm{Q}$, no obvious conformational change is observed for $\mathrm{Q}^{\mathrm{II}}$, with RMSD of $0.94 \AA$ (126 Cas aligned). The two protomers barely interact with each other in 21Q-engaged arrested complex, with a very small buried surface area of $186 \AA^{2}$.

21Q-QBE interactions that mediate $21 Q$ engagement. In the structure of 21Q-engaged arrested complex, the upstream doublestranded DNA (dsDNA) adopts roughly the same orientation as in RPo (Fig. 2c, d). Nevertheless, it is bent by $20^{\circ}$ at QBE subsite 2 due to a network of protein-protein and protein-DNA interactions (Fig. 2c).

QBE subsite 1 and subsite 2 are direct repeats of 6-bp DNA (TGAGCA; Fig. 2a and Supplementary Fig. 1A). Q ${ }^{\mathrm{I}}$ and $\mathrm{Q}^{\mathrm{II}}$ contact subsite 1 and subsite 2 from different faces of the DNA helix, making similar protein-DNA interactions (Fig. 3a and
Supplementary Fig. 6). As expected, the mode of interaction of 21Q with QBE subsites-binding of the second a-helix (H6) of the HTH motif in the DNA major groove-is similar to the mode of interaction of $\sigma \mathrm{R} 4$ with -35 element. Specifically, $\mathrm{H} 5$ residues S93, K94, and $\mathrm{H} 6$ residue T125 are positioned to form two $\mathrm{H}$ bonds and a salt bridge with DNA backbone phosphates, while $\mathrm{H} 5$ residue $\mathrm{H} 95, \mathrm{H} 6$ residues $\mathrm{A} 124, \mathrm{R} 127$, and $\mathrm{R} 128$ are positioned to make $\mathrm{H}$-bonds and van der Waals interactions with DNA bases that potentially enable sequence readout (Fig. 3b and Supplementary Fig. 4D). In addition, L3, the long loop connecting $\mathrm{H} 5$ and $\mathrm{H} 6$, inserts into adjacent DNA minor groove with $\mathrm{R} 113$ positioned to make a $\mathrm{H}$-bond with a DNA base. Consistent with the structure of 21Q-engaged arrested complex, fluorescence-polarization assay shows that substitution of these residues decreases the binding affinity between 21Q and QBE (Fig. 3c). Moreover, substitution of these residues reduces Qdependent read-through, verifying their functional importance (Fig. 3d). Furthermore, both substitutions of the C:G base pairs in QBE subsite 1 (position -21) and subsite 2 (position -13) affect Q-dependent transcription antitermination, verifying that both $\mathrm{Q}^{\mathrm{I}}$-subsite 1 and $\mathrm{Q}^{\mathrm{II}}$-subsite 2 interactions are essential (Fig. 3e).

The crystal structure of $\mathrm{N}$-terminal truncated $\lambda \mathrm{Q}$ shows that it also has a HTH motif analogous to 21Q (Fig. 1e). Genetic and biochemical studies indicate that residues on $\lambda \mathrm{Q} H \mathrm{HTH}$ motif are responsible for $\mathrm{QBE}$ recognition ${ }^{13}$. Thus, $\lambda \mathrm{Q}$ probably interacts with $\mathrm{QBE}$ in a manner similar to $21 \mathrm{Q}$, namely insertion of the second $a$-helix of the HTH motif in the DNA major groove.

$Q^{I}$-RNAP interactions that mediate $Q^{I}$ engagement. Our structure of 21Q-engaged arrested complex reveals that $\mathrm{H} 2$ is detached from the main portion of $\mathrm{Q}^{\mathrm{I}}$ and forms a ring-like structure with L1 and L2 (Supplementary Figs 4B, 5). The main portion of $\mathrm{Q}^{\mathrm{I}}$ sits on the exterior opening of the RNA exit channel and interacts with $\beta^{\prime}$ dock, while the ring inserts into the RNA exit channel and interacts with the zipper, lid, zinc binding domain (ZBD), flap, and $\beta$ C-terminal region ( $\beta$ CTR) (Fig. $4 a, b)$. Specifically, H1 residues W26 and V27 are positioned to make van der Waals interactions with dock residues K395 and T393 (Fig. 4c and Supplementary Fig. 4E), while H2 residues V39, K42, and $\mathrm{S} 46$ are positioned to make van der Waals interactions with zipper residue $\mathrm{F} 49$, lid residue $\mathrm{F} 260$, and $\mathrm{ZBD}$ residue $\mathrm{V} 65$ (Fig. 4d and Supplementary Fig. 4F). A large buried surface area $\left(1384 \AA^{2}\right)$ hints a high-binding affinity between $Q^{I}$ and RNAP. Substitution of the inferred interacting residues decreases 21Qdependent antitermination (Fig. 4e), confirming the functional importance of the inferred interactions. Taking advantage of the observation that Q-engaged complex moves slower than Q-free complex on native gel, electrophoretic mobility shift assays (EMSA) are performed and Q-engaged complex is quantified. The statistics indicate that substitution of the inferred interacting residues affects $\mathrm{Q}$ engagement and DNA interaction (Fig. 4f). However, we can not rule out the possibility that substitution of the inferred interacting residues may affect ring formation, as well.

QII-RNAP interaction that mediates $\mathbf{Q}^{\mathrm{II}}$ engagement. Taking advantage of the flexibility of the flanking linkers, the FTH moves $30 \AA$ relative to its position in RPo and binds to a groove on $\mathrm{Q}^{\mathrm{II}}$ (Fig. 5a and Supplementary Fig. 7). In particular, $\mathrm{H} 4$ residues K79, G82, I83, H90, and H5 residue 197 are positioned to make van der Waals interactions with FTH residues E898, L901, L902, and F906 (Fig. 5b). Q ${ }^{\mathrm{II}}$-RNAP interaction buries a smaller surface area $\left(583 \AA^{2}\right)$ than $Q^{I}$-RNAP interaction $\left(1384 \AA^{2}\right)$, which is consistent with the low binding affinity between 21Q and FTH peptide determined by a fluorescence-polarization assay (Fig. 5c, 
a

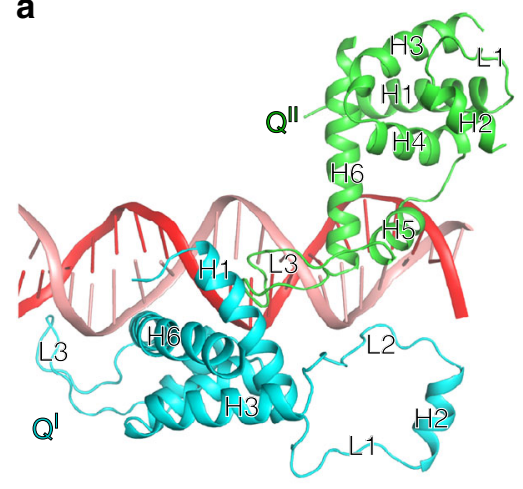

b

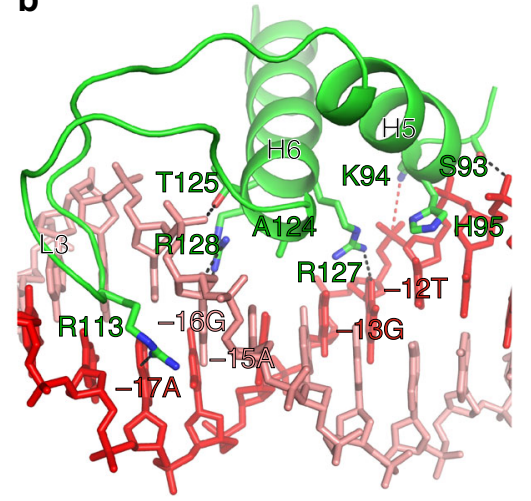

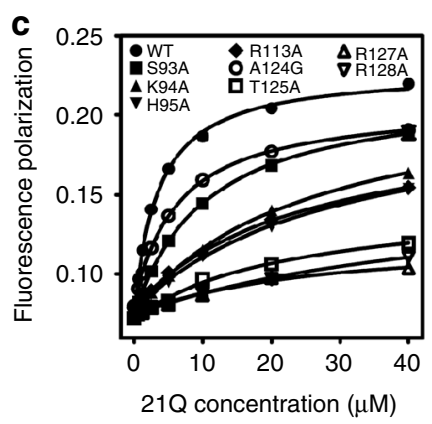
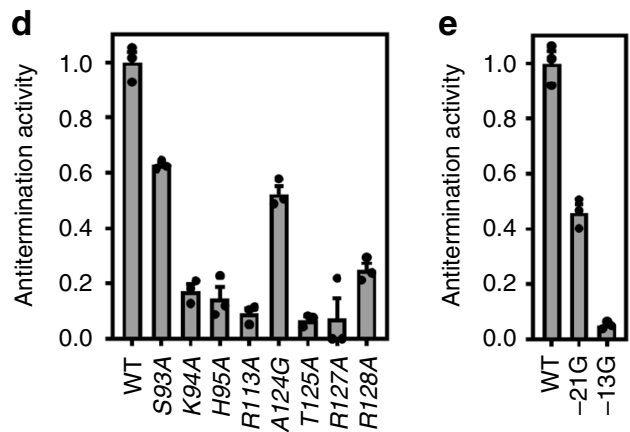

Fig. 3 21Q-QBE interactions that mediate $21 \mathrm{Q}$ engagement. a Ql and Qll contact QBE from different faces of the DNA helix. Cyan, Q'; green, Q"l; salmon, nontemplate strand; red, template strand. b Interactions between Q"I and QBE subsite 2. Salmon sticks, nontemplate strand; red sticks, template strand; black dashed lines, $\mathrm{H}$-bonds ( $\leq 3.5 \AA$ ); red dashed line, salt bridge ( $\leq 4.5 \AA$ ). c Effects on 21Q-QBE binding affinity of substitutions of H5, H6, and L3 (mean $\pm \mathrm{SEM} ; 3$ determinations). d Effects on antitermination of substitutions of $\mathrm{H} 5, \mathrm{H} 6$, and $\mathrm{L} 3$ (mean $\pm \mathrm{SEM} ; 3$ determinations). e Effects on antitermination of substitutions in QBE subsite 1 (position -21) and subsite 2 (position -13), respectively (mean \pm SEM; 3 determinations). Error bars represent mean \pm SEM out of $n=3$ experiments. Source data are provided as a Source Data file

a
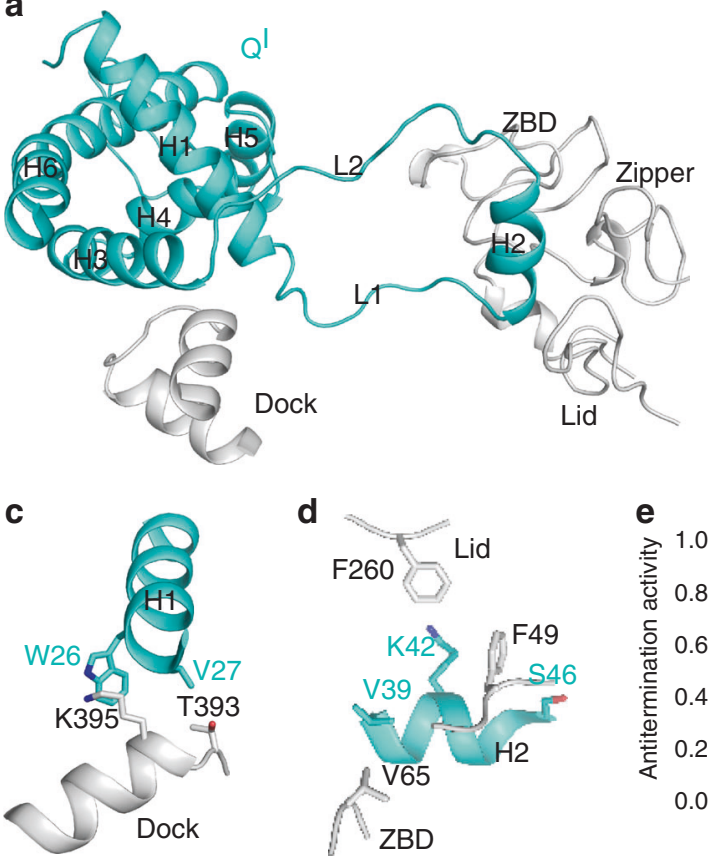

d

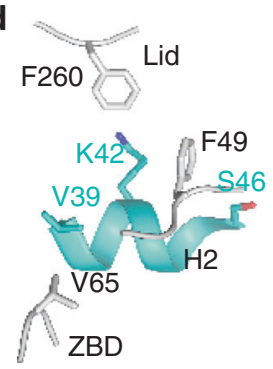

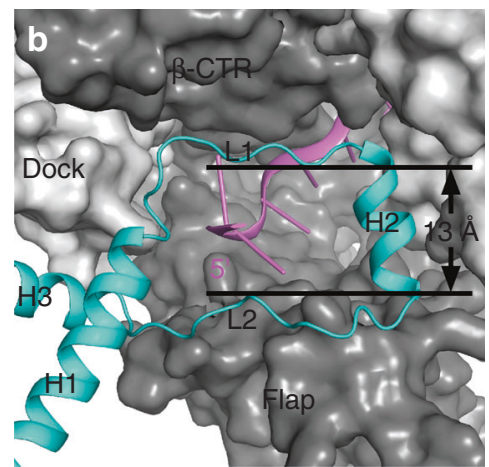

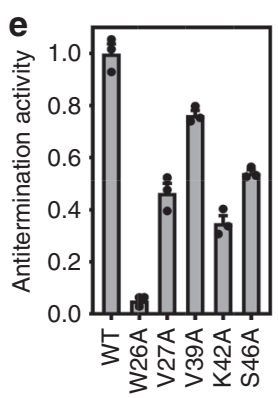

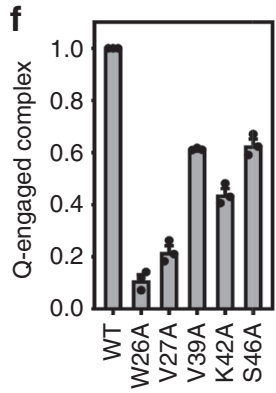

Fig. 4 Q'-RNAP interactions that mediate $Q^{\prime}$ engagement. a The main portion of $Q^{\prime}$ interacts with $\beta^{\prime}$ dock, while $H 2$ inserts into the RNA exit channel and interacts with the zipper, lid, and ZBD. Cyan, $Q^{\prime}$; gray, $\beta^{\prime} . \mathbf{b} \mathrm{H} 2, \mathrm{~L} 1$, and $\mathrm{L} 2$ form a ring-like structure inside the RNA exit channel. RNAP is shown as surface. ZBD is omitted for clarity. Dark gray, $\beta$; light gray, $\beta^{\prime}$; cyan, $Q^{\prime}$; pink, RNA. c Interactions between $\mathrm{H} 1$ and $\beta^{\prime}$ dock. $\mathbf{d}$ Interactions between $\mathrm{H} 2$ and the zipper, lid, and ZBD. e Effects on antitermination of substitutions of $\mathrm{H} 1$ and $\mathrm{H} 2$ (mean $\pm \mathrm{SEM} ; 3$ determinations). $\mathbf{f}$ Effects on $\mathrm{Q}$ engagement of substitutions of $\mathrm{H} 1$ and $\mathrm{H} 2$ (mean $\pm \mathrm{SEM} ; 4$ determinations). Error bars represent mean \pm SEM out of $n=3$ experiments. Source data are provided as a Source Data file 

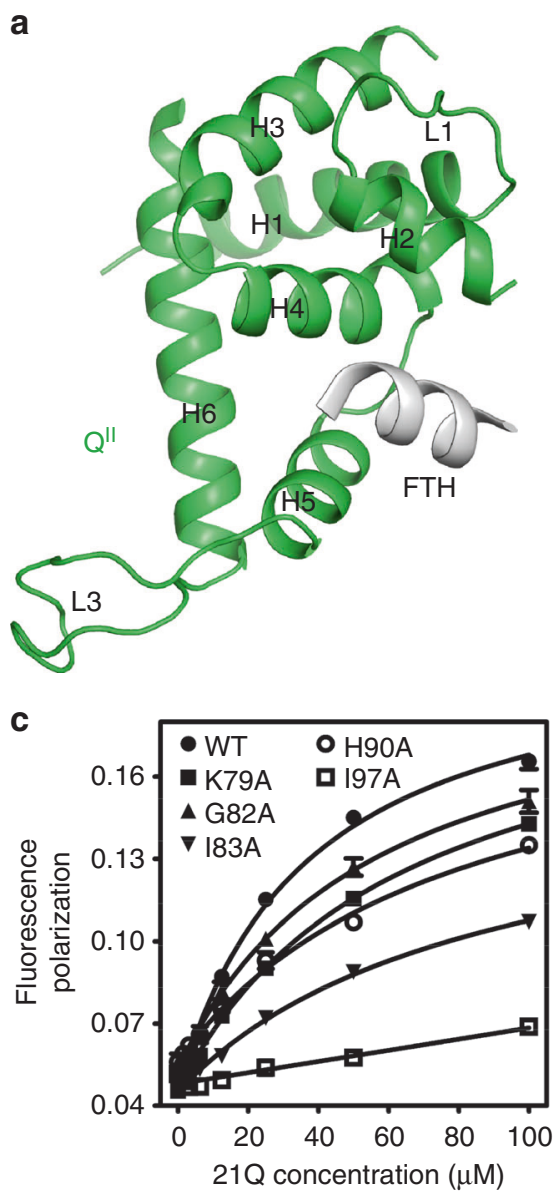

b
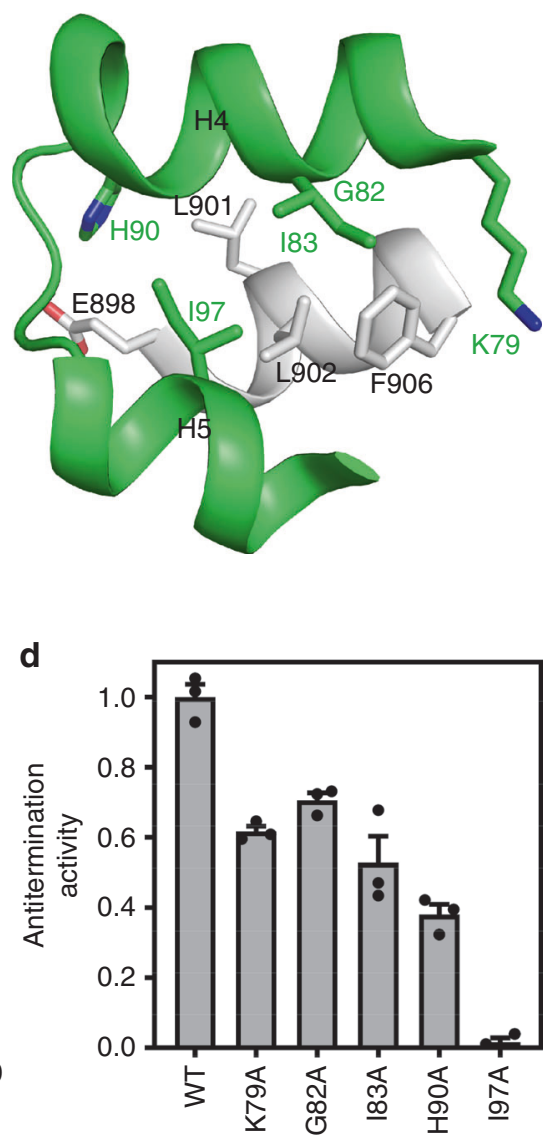

Fig. 5 Q"I-RNAP interaction that mediates Q" engagement. a The FTH binds to a groove on Q"l. Green, Q"l; gray, FTH. b Interactions between H4, H5 and FTH. c Effects on 21Q-FTH binding affinity of substitutions of $\mathrm{H} 4$ and $\mathrm{H} 5$ (mean \pm SEM; 3 determinations). $\mathbf{d}$ Effects on antitermination of substitutions of $\mathrm{H} 4$ and H5 (mean \pm SEM; 3 determinations). Error bars represent mean \pm SEM out of $n=3$ experiments. Source data are provided as a Source Data file

$\left.K_{\mathrm{D}}=37 \mu \mathrm{M}\right)$. Substitution of residues implicated in $\mathrm{Q}^{\mathrm{II}}-\mathrm{FTH}$ interaction results in decreased binding affinity and 21Qdependent antitermination (Fig. $5 c$, d), indicating that the inferred interactions occur and are important. In accordance, genetic and biochemical studies showed that $\lambda \mathrm{Q}$ also established direct contacts with the FTH during the engagement process ${ }^{24}$.

Absence of interaction between 21Q and $\sigma$. It was reported that $\lambda \mathrm{Q}$ interacted with $\sigma \mathrm{R} 4$, stabilizing the binding of $\sigma \mathrm{R} 4$ to the -35-like sequence embedded within the late gene promoter of bacteriophage $\lambda^{14}$. However, $\sigma \mathrm{R} 4$ is disordered in our structure of 21Q-engaged arrested complex, which is consistent with the observation that there is no -35 -like sequence in $21 \mathrm{P}_{\mathrm{R}^{\prime}}$ (Fig. $2 \mathrm{a}$ and Supplementary Fig. 1A).

\section{Discussion}

A pathway for formation of a Q-dependent termination-resistant elongation complex can be drawn based on this work and previous structural and biochemical studies (Fig. 6). During transcription initiation, $\sigma \mathrm{R} 4$ and $\sigma \mathrm{R} 2$ are anchored to RNAP and make sequence specific contacts with the promoter -35 element and the promoter -10 element, respectively ${ }^{1-8}$. After promoter escape, $\sigma \mathrm{R} 3.2$ and $\sigma \mathrm{R} 4$ are sequentially displaced because of the steric clashes between $\sigma \mathrm{R} 3.2, \sigma \mathrm{R} 4$, and the nascent RNA, while $\sigma \mathrm{R} 2$ is retained ${ }^{1,25-27}$. If $\mathrm{a}-10$-like sequence is encountered, $\sigma \mathrm{R} 2$ will make exactly the same contacts with it as in RPo, which will lead to $\sigma$-dependent pause ${ }^{10-12,23}$. The interaction between the upstream fork junction of the transcription bubble and $\sigma \mathrm{R} 2$ restrains the conformation of upstream dsDNA so that QBE is located in the vicinity of the RNA exit channel. Taking advantage of the pause, $\mathrm{Q}^{\mathrm{I}}$ and $\mathrm{Q}^{\mathrm{II}}$ bind to $\mathrm{QBE}$ and interact with distinct elements of the RNA exit channel (i.e., the dock, ZBD, zipper, lid, flap, and $\beta$ CTR for $Q^{\mathrm{I}}$; the FTH for $\left.\mathrm{Q}^{\mathrm{II}}\right)$. Both $\mathrm{Q}^{\mathrm{I}}$ and $\mathrm{Q}^{\mathrm{II}}$ contribute to the intricate interactions that stabilize $\mathrm{Q}$-engaged complex and bend the upstream dsDNA by $20^{\circ}$. Since the QBE of the upstream dsDNA and the -10-like sequence of the transcription bubble are tightly anchored to RNAP through $\mathrm{Q}^{\mathrm{I}}, \mathrm{Q}^{\mathrm{II}}$, and $\sigma \mathrm{R} 2$, further extension of the nascent RNA leads to scrunching as in initial transcription ${ }^{28,29}$. If the energy stored in the scrunch is insufficient to disrupt the anchoring, RNAP backtracks into an arrested state analogous to the state in our cryo-EM structure, and cleavage of the backtracked RNA must occur in order to resume transcription ${ }^{18}$. If the energy stored in the scrunch is sufficient to disrupt the anchoring, RNAP escapes from the arrested state and resumes elongation. Considering that the equilibrium dissociation constant for $\mathrm{Q}^{\mathrm{II}}-\mathrm{FTH}$ interaction $\left(K_{\mathrm{D}}=37 \mu \mathrm{M}\right)$ is much higher than the working concentration of 21Q $(0.1 \mu \mathrm{M}), \mathrm{Q}^{\mathrm{II}}$ probably dissociates after arrest escape. Considering that the buried surface area for $\mathrm{Q}^{\mathrm{I}}-\mathrm{RNAP}$ interaction is twice of the buried surface area for $\mathrm{Q}^{\mathrm{II}}-\mathrm{RNAP}$ interaction, $\mathrm{Q}^{\mathrm{I}}$ is probably retained and travels along with RNAP after arrest escape.

A long-standing question has been how $\mathrm{Q}$ renders RNAP resistant to intrinsic terminators, which are transcribed to form a GC-rich hairpin followed by a 7-8 nt U-tract ${ }^{30}$. According to the 


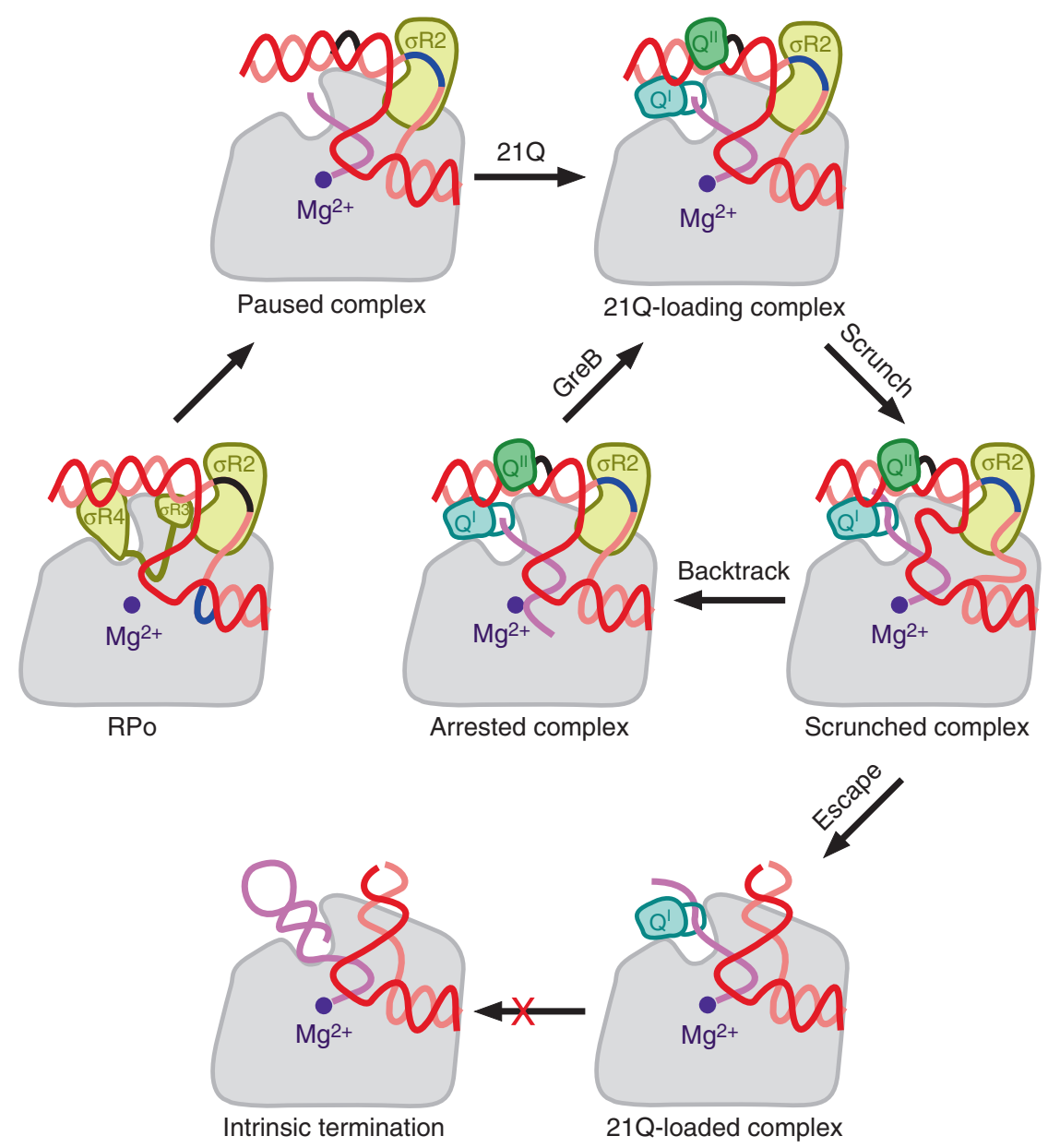

Fig. 6 Pathway for formation of a 21Q-dependent termination-resistant elongation complex. Gray, RNAP; cyan, Q'; green, Q"l; yellow, $\sigma^{70}$; violet, active center $\mathrm{Mg}^{2+}$; salmon, nontemplate strand; red, template strand; pink, RNA; black, the promoter -10 element; blue, the -10 -like sequence

structure of 21Q-engaged arrested complex, the ring-like structure of $\mathrm{Q}^{\mathrm{I}}$ inserts into the RNA exit channel and serves as a gate (Fig. 4b). Because the side chains of L1 and L2 residues are not modeled due to their weak density map (Supplementary Fig. 4B), the width of the gate cannot be measured. However, it should be less than $13 \AA$ (the shortest distance between Cas; Fig. 4b), which is too small to accommodate RNA hairpin (diameter $>20 \AA)^{31,32}$. Therefore, we infer that $\mathrm{Q}^{\mathrm{I}}$ renders RNAP resistant to intrinsic termination by prohibiting RNA hairpin formation in the RNA exit channel.

Cryo-EM structures of protein $\mathrm{N}$, another antiterminator from bacteriophage, in complex with RNAP along with other host factors have been reported 33,34 . Due to its intrinsic disorder, it can thereby adopt a highly elongated conformation, bridge large distances, and interact with RNA, upstream DNA, the hybrid, host factors, and various elements of RNAP that are remote from each other. In contrast with N, 21Q and likely other Q proteins are positioned in a similar locale and only contact elements of the RNA exit channel.

In conclusion, the structure of $21 \mathrm{Q}$-engaged arrested complex defines the mechanisms by which $21 \mathrm{Q}$ loads onto and alters the functional properties of elongation complex. The structure demonstrates that the RNA exit channel can serve as a direct target for regulators of transcription elongation. Because the RNA exit channel is a conserved feature of all multisubunit RNAPs ${ }^{35}$, it is likely to serve as an important contact site for regulators that modify the elongation properties of RNAP in other organisms, as well.

\section{Methods}

Bacteriophage $21 \mathbf{Q}$ protein. E. coli strain BL21(DE3) (Invitrogen, Inc.) was transformed with plasmid pET28a-21Q (GENEWIZ, Inc.) encoding 21Q under control of the bacteriophage T7 gene 10 promoter, or with a pET28a-21Q derivative constructed by use of site-directed mutagenesis (QuikChange Site-Directed Mutagenesis Kit; Agilent, Inc.). Single colonies of the resulting transformants were used to inoculate $50 \mathrm{ml} \mathrm{LB}$ broth containing $50 \mu \mathrm{g} / \mathrm{ml}$ kanamycin, and cultures were incubated $16 \mathrm{~h}$ at $37^{\circ} \mathrm{C}$ with shaking. Aliquots $(10 \mathrm{ml})$ were used to inoculate $11 \mathrm{LB}$ broth containing $50 \mu \mathrm{g} / \mathrm{ml}$ kanamycin, cultures were incubated at $37^{\circ} \mathrm{C}$ with shaking until $\mathrm{OD}_{600}=0.6$, cultures were induced by addition of IPTG to $1 \mathrm{mM}$, and cultures were incubated $18 \mathrm{~h}$ at $16^{\circ} \mathrm{C}$. Then cells were harvested by centrifugation $\left(5000 \times \mathrm{g} ; 15 \mathrm{~min}\right.$ at $\left.4^{\circ} \mathrm{C}\right)$, resuspended in $20 \mathrm{ml}$ buffer A $(10 \mathrm{mM}$ Tris$\mathrm{HCl}, \mathrm{pH}$ 7.5, $0.2 \mathrm{M} \mathrm{NaCl}, 5 \%$ glycerol, $1 \mathrm{mM} \mathrm{EDTA}$, and $1 \mathrm{mM} \mathrm{DTT}$ ) and lysed using a JN-02C cell disrupter (JNBIO, Inc.). The lysate was centrifuged $(20,000 \times g$; $30 \mathrm{~min}$ at $4^{\circ} \mathrm{C}$ ), and the supernatant was loaded onto a $5 \mathrm{ml}$ column of HiTrap Heparin HP (GE Healthcare, Inc.) equilibrated in buffer A and eluted with a $100 \mathrm{ml}$ linear gradient of $0.2-1 \mathrm{M} \mathrm{NaCl}$ in buffer $\mathrm{A}$. The sample was further purified by cation-exchange chromatography on a Mono S 10/100 GL column (GE Healthcare, Inc.; $160 \mathrm{ml}$ linear gradient of $0.2-1 \mathrm{M} \mathrm{NaCl}$ in buffer A). Fractions containing $21 \mathrm{Q}$ were pooled and stored at $-80^{\circ} \mathrm{C}$. Yields were $\sim 1-10 \mathrm{mg} / \mathrm{L}$, and purities were $>95 \%$.

E. coli $\boldsymbol{\sigma}^{\mathbf{7 0}}$. E. coli strain BL21(DE3) (Invitrogen, Inc.) was transformed with plasmid pGEMD ${ }^{36}$. Single colonies of the resulting transformants were used to inoculate $50 \mathrm{ml} \mathrm{LB}$ broth containing $100 \mu \mathrm{g} / \mathrm{ml}$ ampicillin, and cultures were incubated $16 \mathrm{~h}$ at $37^{\circ} \mathrm{C}$ with shaking. Aliquots $(10 \mathrm{ml})$ were used to inoculate $11 \mathrm{LB}$ broth containing $100 \mu \mathrm{g} / \mathrm{ml}$ ampicillin, cultures were incubated at $37^{\circ} \mathrm{C}$ with shaking until $\mathrm{OD}_{600}=0.6$, cultures were induced by addition of IPTG to $1 \mathrm{mM}$, and cultures were incubated $3 \mathrm{~h}$ at $37^{\circ} \mathrm{C}$. Then cells were harvested by centrifugation $\left(5000 \times \mathrm{g} ; 15 \mathrm{~min}\right.$ at $\left.4^{\circ} \mathrm{C}\right)$, resuspended in $20 \mathrm{ml}$ buffer C $(40 \mathrm{mM}$ Tris$\mathrm{HCl}, \mathrm{pH} 7.9,0.3 \mathrm{M} \mathrm{KCl}, 10 \mathrm{mM}$ EDTA, and $1 \mathrm{mM}$ DTT) and lysed using a JN-02C cell disrupter (JNBIO, Inc.). After centrifugation $\left(20,000 \times g ; 30 \mathrm{~min}\right.$ at $\left.4{ }^{\circ} \mathrm{C}\right)$, the pellet was washed with $25 \mathrm{ml}$ buffer C twice, resuspended in buffer D ( $40 \mathrm{mM}$ Tris$\mathrm{HCl}$, pH7.9, $6 \mathrm{M} \mathrm{GuHCl}, 1 \mathrm{mM}$ EDTA, and 10\% glycerol), and dialyzed against $3 \times$ 
11 buffer E (20 mM Tris-HCl, pH7.9, $0.2 \mathrm{M} \mathrm{NaCl}, 1 \mathrm{mM}$ EDTA, and $5 \mathrm{mM} \beta$ mercaptoethanol) for three times. After centrifugation $\left(20,000 \times g ; 30 \mathrm{~min}\right.$ at $\left.4^{\circ} \mathrm{C}\right)$, the supernatant was loaded onto a Mono Q 10/100 GL column (GE Healthcare, Inc.) equilibrated in buffer F (10 mM Tris-HCl, pH7.9, 1 mM EDTA, $1 \mathrm{mM}$ DTT, and $5 \%$ glycerol) and eluted with a $160 \mathrm{ml}$ linear gradient of $0.3-0.5 \mathrm{M} \mathrm{NaCl}$ in buffer F. Fractions containing E. coli $\sigma^{70}$ were pooled and stored at $-80^{\circ} \mathrm{C}$. Yield was $\sim 50 \mathrm{mg} / \mathrm{L}$, and purity was $>95 \%$.

E. coli RNAP core enzyme. E. coli RNAP core enzyme was prepared from E. coli strain BL21(DE3) (Invitrogen, Inc.) transformed with plasmid pIA900 37. Single colonies of the resulting transformants were used to inoculate $50 \mathrm{ml} \mathrm{LB}$ broth containing $100 \mu \mathrm{g} / \mathrm{ml}$ ampicillin, and cultures were incubated $16 \mathrm{~h}$ at $37^{\circ} \mathrm{C}$ with shaking. Aliquots $(10 \mathrm{ml})$ were used to inoculate $1 \mathrm{l} \mathrm{LB}$ broth containing $100 \mu \mathrm{g} / \mathrm{ml}$ ampicillin, cultures were incubated at $37^{\circ} \mathrm{C}$ with shaking until $\mathrm{OD}_{600}=0.6$, cultures were induced by addition of IPTG to $1 \mathrm{mM}$, and cultures were incubated $3 \mathrm{~h}$ at $37^{\circ} \mathrm{C}$. Then cells were harvested by centrifugation $\left(5000 \times g ; 15\right.$ min at $\left.4{ }^{\circ} \mathrm{C}\right)$, resuspended in $20 \mathrm{ml}$ lysis buffer ( $50 \mathrm{mM}$ Tris- $\mathrm{HCl}, \mathrm{pH} 7.9,0.2 \mathrm{M} \mathrm{NaCl}, 2 \mathrm{mM}$ EDTA, 5\% glycerol, and $5 \mathrm{mM}$ DTT) and lysed using a JN-02C cell disrupter (JNBIO, Inc.). After poly(ethyleneimine) precipitation and ammonium sulfate precipitation, the pellet was resuspended in buffer $\mathrm{G}(10 \mathrm{mM}$ Tris- $\mathrm{HCl}, \mathrm{pH} 7.9,0.5$ $\mathrm{M} \mathrm{NaCl}$, and $5 \%$ glycerol) and loaded onto a $5 \mathrm{ml}$ column of Ni-NTA agarose (Qiagen, Inc.) equilibrated with buffer G. The column was washed with $25 \mathrm{ml}$ buffer $\mathrm{G}$ containing $20 \mathrm{mM}$ imidazole and eluted with $25 \mathrm{ml}$ buffer $\mathrm{G}$ containing $0.15 \mathrm{M}$ imidazole. The eluate was diluted in buffer $\mathrm{F}$ and loaded onto a Mono Q 10/ $100 \mathrm{GL}$ column (GE Healthcare, Inc.) equilibrated in buffer $\mathrm{F}$ and eluted with a $160 \mathrm{ml}$ linear gradient of $0.3-0.5 \mathrm{M} \mathrm{NaCl}$ in buffer F. Fractions containing E. coli RNAP core enzyme were pooled and stored at $-80^{\circ} \mathrm{C}$. Yield was $\sim 2.5 \mathrm{mg} / \mathrm{L}$, and purity was $>95 \%$.

E. coli RNAP- $\boldsymbol{\sigma}^{\mathbf{7 0}}$ holoenzyme. E. coli RNAP core enzyme and E. coli $\sigma^{70}$ were incubated in a $1: 4$ ratio for $1 \mathrm{~h}$ at $4{ }^{\circ} \mathrm{C}$. The reaction mixture was applied to a HiLoad 16/600 Superdex 200 column (GE Healthcare, Inc.) equilibrated in $10 \mathrm{mM}$ HEPES, pH 7.5, and $50 \mathrm{mM} \mathrm{KCl}$, and the column was eluted with $120 \mathrm{ml}$ of the same buffer. Fractions containing E. coli RNAP- $\sigma^{70}$ holoenzyme were pooled and stored at $-80^{\circ} \mathrm{C}$.

GreB. E. coli strain BL21(DE3) (Invitrogen, Inc.) was transformed with plasmid pMO1.4His encoding N-hexahistidine-tagged GreB under the control of the trc promoter $^{38}$. Single colonies of the resulting transformants were used to inoculate $50 \mathrm{ml} \mathrm{LB}$ broth containing $100 \mu \mathrm{g} / \mathrm{ml}$ ampicillin, and cultures were incubated $16 \mathrm{~h}$ at $37^{\circ} \mathrm{C}$ with shaking. Aliquots $(10 \mathrm{ml})$ were used to inoculate $11 \mathrm{LB}$ broth containing $100 \mu \mathrm{g} / \mathrm{ml}$ ampicillin, cultures were incubated at $37^{\circ} \mathrm{C}$ with shaking until $\mathrm{OD}_{600}=0.6$, cultures were induced by addition of IPTG to $1 \mathrm{mM}$, and cultures were incubated an additional $3 \mathrm{~h}$ at $37^{\circ} \mathrm{C}$. Cells were harvested by centrifugation $\left(5000 \times g ; 15 \mathrm{~min}\right.$ at $\left.4^{\circ} \mathrm{C}\right)$, resuspended in $20 \mathrm{ml}$ buffer B $(40 \mathrm{mM}$ Tris- $\mathrm{HCl}, \mathrm{pH} 7.5$, $0.8 \mathrm{M} \mathrm{NaCl}$ ) and lysed using a JN-02C cell disrupter (JNBIO, Inc.). The lysate was centrifuged $\left(20,000 \times g ; 30 \mathrm{~min}\right.$ at $\left.4{ }^{\circ} \mathrm{C}\right)$, and the supernatant was loaded onto a $2 \mathrm{ml}$ column of Ni-NTA agarose (Qiagen, Inc.) equilibrated with buffer B. The column was washed with $10 \mathrm{ml}$ buffer $B$ containing $0.25 \mathrm{M}$ imidazole and eluted with $10 \mathrm{ml}$ buffer B containing $0.6 \mathrm{M}$ imidazole. The eluate was concentrated to $2 \mathrm{ml}$ using an Amicon Ultra-15 centrifugal filter (10 kDa MWCO; Merck Millipore, Inc.) and applied to a HiLoad 16/600 Superdex 200 column (GE Healthcare, Inc.) equilibrated in $40 \mathrm{mM}$ Tris- $\mathrm{HCl}, \mathrm{pH} 7.5,0.8 \mathrm{M} \mathrm{NaCl}, 1 \mathrm{mM}$ EDTA, and $1 \mathrm{mM}$ DTT, and the column was eluted with $120 \mathrm{ml}$ of the same buffer. Fractions containing GreB were pooled and stored at $-80^{\circ} \mathrm{C}$. Yield was $\sim 2.5 \mathrm{mg} / \mathrm{L}$, and purity was $>95 \%$.

Mango III transcription antitermination assay. A DNA fragment corresponding to -148 to +214 of the bacteriophage 21 late gene promoter ${ }^{16}$ followed by Mango III coding sequence ${ }^{17}$ was synthesized and inserted into pUC57 (GENEWIZ, Inc.). The DNA fragment was amplified by PCR, was purified using the QIAquick PCR Purification Kit (Qiagen, Inc.), and was stored at $-80^{\circ} \mathrm{C}$. Transcription antitermination assay was performed in a 384-well microplate format. Reaction mixtures contained $(50 \mu \mathrm{l}): 0$ or $0.1 \mu \mathrm{M} 21 \mathrm{Q}, 0$ or $0.1 \mu \mathrm{M}$ GreB, $0.1 \mu \mathrm{M}$ E. coli RNAP$\sigma^{70}$ holoenzyme, $20 \mathrm{nM}$ DNA fragment, $1 \mu \mathrm{M}$ TO1-Biotin, $0.2 \mathrm{mM}$ ATP, $0.2 \mathrm{mM}$ UTP, $0.2 \mathrm{mM}$ GTP, $0.2 \mathrm{mM}$ CTP, $50 \mathrm{mM}$ Tris- $\mathrm{HCl}$, pH 8.0, $0.1 \mathrm{M} \mathrm{KCl}, 10 \mathrm{mM}$ $\mathrm{MgCl}_{2}, 1 \mathrm{mM}$ DTT, and $5 \%$ glycerol. Following incubation for $20 \mathrm{~min}$ at $37^{\circ} \mathrm{C}$, fluorescence emission intensities were measured using a Varioskan Flash Multimode Reader (ThermoFisher, Inc.; excitation wavelength $=510 \mathrm{~nm}$; emission wavelength $=535 \mathrm{~nm}$ ). Relative antitermination activities of $21 \mathrm{Q}$ derivatives were calculated using:

$$
A=\left(I-I_{0}\right) /\left(I_{\mathrm{WT}}-I_{0}\right)
$$

where $I_{\mathrm{WT}}$ and $I$ are the fluorescence intensities in the presence of $21 \mathrm{Q}$ and $21 \mathrm{Q}$ derivatives, while $I_{0}$ is the fluorescence intensity in the absence of $21 \mathrm{Q}$.

Crystallization and cryo-cooling. Crystallization trails were performed using commercial screening solutions (Hampton Research, Inc. and Qiagen, Inc.) and the hanging-drop vapor diffusion technique (drop: $1 \mu \mathrm{l}$ protein plus $1 \mu \mathrm{l}$ screening solution; reservoir: $400 \mu \mathrm{l}$ screening solution; $23^{\circ} \mathrm{C}$ ). A total of 300 conditions were screened. Under several conditions, crystals appeared within 1 week. The optimized condition (drop: $1 \mu \mathrm{l}$ protein plus $1 \mu \mathrm{l} 0.2 \mathrm{M} \mathrm{KF}$ and 14\% PEG3350; reservoir: $400 \mu$ $0.2 \mathrm{M} \mathrm{KF}$ and $14 \%$ PEG $3350 ; 23^{\circ} \mathrm{C}$ ) yielded high-quality, plate-like crystals with dimensions of $0.1 \mathrm{~mm} \times 0.1 \mathrm{~mm} \times 0.05 \mathrm{~mm}$ in 1 week. Crystals were transferred to reservoir solution containing $10 \%(\mathrm{v} / \mathrm{v})$ glycerol and flash-cooled with liquid nitrogen.

Crystal data collection and structure solution. Diffraction data were collected from cryo-cooled crystals at Shanghai Synchrotron Radiation Facility (SSRF) beamline $17 \mathrm{U}$, processed using HKL2000 ${ }^{39}$. The structure was solved by molecular replacement with Molrep ${ }^{40}$ using the structure of $\sigma \mathrm{R} 4$ in complex with anti- $\sigma$ RseA (PDB 1OR7 [https://doi.org/10.2210/pdb1OR7/pdb]) $)^{19}$ as the search model. The model of 21Q was built in $\operatorname{Coot}^{41}$ and refined in Phenix ${ }^{42}$.

Radioactive transcription assay. DNA oligonucleotides (Sangon Biotech, Inc.) were dissolved in nuclease-free water to $\sim 1 \mathrm{mM}$ and stored at $-80^{\circ} \mathrm{C}$. Template strand DNA and nontemplate strand DNA were annealed at a 1:1 ratio in $10 \mathrm{mM}$ Tris- $\mathrm{HCl}, \mathrm{pH} 7.9,0.2 \mathrm{M} \mathrm{NaCl}$ and stored at $-80^{\circ} \mathrm{C}$. Radioactive transcription assay was performed in reaction mixtures containing $(20 \mu \mathrm{l}): 0.1 \mu \mathrm{M} 21 \mathrm{Q}, 0$ or $0.1 \mu \mathrm{M}$ GreB, $0.1 \mu \mathrm{M}$ E. coli RNAP- $\sigma^{70}$ holoenzyme, $20 \mathrm{nM}$ DNA scaffold, $50 \mathrm{mM}$ Tris$\mathrm{HCl}, \mathrm{pH} 8.0,0.1 \mathrm{M} \mathrm{KCl}, 10 \mathrm{mM} \mathrm{MgCl}_{2}, 1 \mathrm{mM}$ DTT, and 5\% glycerol. Reaction mixtures were incubated $5 \mathrm{~min}$ at $37^{\circ} \mathrm{C}$, supplemented with $0.2 \mathrm{mM}$ ATP, $0.2 \mathrm{mM}$ UTP, $0.2 \mathrm{mM}$ GTP, and $0.2 \mu \mathrm{l} 3.3 \mu \mathrm{M}\left[\alpha^{-32} \mathrm{P}\right] \mathrm{UTP}(100 \mathrm{~Bq} / \mathrm{fmol})$, and RNA synthesis was allowed to proceed for $20 \mathrm{~min}$ at $37^{\circ} \mathrm{C}$. Reactions were terminated by adding $10 \mu$ loading buffer ( $10 \mathrm{mM}$ EDTA, $0.02 \%$ bromophenol blue, $0.02 \%$ xylene cyanol, and $98 \%$ formamide) and boiling for $5 \mathrm{~min}$. Products were applied to $15 \%$ urea-polyacrylamide slab gels (19:1 acrylamide/bisacrylamide), electrophoresed in $90 \mathrm{mM}$ Tris-borate, $\mathrm{pH} 8.0$, and $0.2 \mathrm{mM}$ EDTA, and analyzed by storage-phosphor scanning (Typhoon; GE Healthcare, Inc.)

Assembly of 21Q-engaged arrested complex. 21Q-engaged arrested complex was prepared using the same DNA scaffold as the radioactive transcription assay. Reaction mixture contained $(5 \mathrm{ml}): 0.4 \mu \mathrm{M} 21 \mathrm{Q}, 0.1 \mu \mathrm{M}$ E. coli RNAP- $\sigma^{70}$ holoenzyme, $0.11 \mu \mathrm{M}$ DNA scaffold, $50 \mathrm{mM}$ Tris- $\mathrm{HCl}$, pH 8.0, $0.1 \mathrm{M} \mathrm{KCl}, 10 \mathrm{mM}$ $\mathrm{MgCl}_{2}$, and $1 \mathrm{mM} \mathrm{DTT}$. Reaction mixture was incubated $10 \mathrm{~min}$ at $37^{\circ} \mathrm{C}$, supplemented with $1 \mathrm{mM}$ ATP, $1 \mathrm{mM}$ UTP, and $1 \mathrm{mM}$ GTP, and RNA synthesis was allowed to proceed for $10 \mathrm{~min}$ at $37^{\circ} \mathrm{C}$. Reaction mixture was concentrated to 13 $\mu \mathrm{M}$ using an Amicon Ultra- $0.5 \mathrm{ml}$ centrifugal filter (10 kDa MWCO; Merck Millipore, Inc.).

Cryo-EM grid preparation. Immediately before freezing, $8 \mathrm{mM}$ CHAPSO was added to the sample. C-flat grids (CF-1.2/1.3-4 C; Protochips, Inc.) were glowdischarged for $60 \mathrm{~s}$ at $15 \mathrm{~mA}$ prior to the application of $3 \mu \mathrm{l}$ of the complex, then plunge-frozen in liquid ethane using a Vitrobot (FEI, Inc.) with 95\% chamber humidity at $10^{\circ} \mathrm{C}$.

Cryo-EM data acquisition and processing. The grids were imaged using a $300 \mathrm{kV}$ Titan Krios (FEI, Inc.) equipped with a K2 Summit direct electron detector (Gatan, Inc.). Images were recorded with Serial $\mathrm{EM}^{43}$ in counting mode with a physical pixel size of $1.307 \AA$ and a defocus range of $1.5-2.5 \mu \mathrm{m}$. Data were collected with a dose of $8 \mathrm{e} / \mathrm{pixel} / \mathrm{s}$. Images were recorded with a $12 \mathrm{~s}$ exposure and $0.25 \mathrm{~s}$ subframes to give a total dose of $56 \mathrm{e} / \AA^{2}$. Subframes were aligned and summed using MotionCor $2^{44}$. The contrast transfer function was estimated for each summed image using CTFFIND $4^{45}$. From the summed images, $\sim 10,000$ particles were manually picked and subjected to $2 \mathrm{D}$ classification in RELION ${ }^{46}$. $2 \mathrm{D}$ averages of the best classes were used as templates for auto-picking in RELION. Auto-picked particles were manually inspected, then subjected to $2 \mathrm{D}$ classification in RELION Poorly populated classes were removed, resulting in a dataset of 279,736 particles. These particles were 3D classified in RELION using a map of $E$. coli elongation complex (EMD-8585 [https://www.emdataresource.org/EMD-8585]) ${ }^{22}$ low-pass filtered to $40 \AA$ resolution as a reference. 3D classification resulted in 4 classes. Particles in Class 2 were 3D auto-refined, then subjected to 3D classification focused on QBE. From this classification, the best-resolved class containing 64,497 particles was 3D auto-refined and post-processed in RELION.

Cryo-EM model building and refinement. The model of RNAP from the structure of $E$. coli elongation complex (PDB 6ALF [https://doi.org/10.2210/pdb6ALF/pdb]) ${ }^{22}$, the models of $\sigma \mathrm{R} 1.2, \sigma \mathrm{R} 2$, and FTH from the structure of E. coli RPo (PDB 6CA0 [https://doi.org/10.2210/pdb6CA0/pdb] $)^{7}$, and the model of 21Q crystal structure were fitted into the cryo-EM density map using Chimera ${ }^{47}$. The model of nucleic acids was built manually in $\mathrm{Coot}^{41}$. The coordinates were real-space refined with secondary structure restraints in Phenix ${ }^{42}$.

Fluorescence polarization assays of 21Q-QBE interaction. 5' 6-FAM labeled template strand DNA oligonucleotide (5'-TGTTGCTCATTTGC-3', Sangon Biotech, Inc.) and nontemplate strand DNA oligonucleotide (5'-GCAAATGAGCAACA-3', Sangon Biotech, Inc.) were annealed at a 1:1 ratio in $10 \mathrm{mM}$ Tris- $\mathrm{HCl}$, $\mathrm{pH} 7.9,0.2 \mathrm{M} \mathrm{NaCl}$ and stored at $-80^{\circ} \mathrm{C}$. Equilibrium fluorescence polarization 
assays were performed in a 96-well microplate format. Reaction mixtures contained (100 $\mu \mathrm{l}$ ): $0-40 \mu \mathrm{M} 21 \mathrm{Q}$ or $21 \mathrm{Q}$ derivative, $0.1 \mu \mathrm{M}$ 6-FAM-labeled DNA scaffold, 50 $\mathrm{mM}$ Tris- $\mathrm{HCl}, \mathrm{pH} 8.0,0.1 \mathrm{M} \mathrm{KCl}, 10 \mathrm{mM} \mathrm{MgCl}_{2}, 1 \mathrm{mM} \mathrm{DTT}$, and $5 \%$ glycerol. Following incubation mixtures for $10 \mathrm{~min}$ at $25^{\circ} \mathrm{C}$, fluorescence emission intensities were measured using a SpectraMax M5 microplate reader (Molecular Devices, Inc.; excitation wavelength $=494 \mathrm{~nm}$; emission wavelength $=518 \mathrm{~nm}$ ). Fluorescence polarization was calculated using:

$$
P=\left(I_{\mathrm{VV}}-I_{\mathrm{VH}}\right) /\left(I_{\mathrm{VV}}+I_{\mathrm{VH}}\right)
$$

where $I_{\mathrm{VV}}$ and $I_{\mathrm{VH}}$ are fluorescence intensities with the excitation polarizer at the vertical position and the emission polarizer at, respectively, the vertical position and the horizontal position.

Equilibrium dissociation constant, $K_{\mathrm{D}}$, were extracted by non-linear regression using the equation:

$$
P=P_{f}+\left\{\left(P_{b}-P_{f}\right) \mathrm{x}[\mathrm{T}] /\left(K_{D}+[\mathrm{T}]\right)\right\}
$$

where $P$ is the fluorescence polarization at a given concentration of $21 \mathrm{Q}, P_{\mathrm{f}}$ is the fluorescence polarization for free 6-FAM-labeled DNA scaffold, $P_{\mathrm{b}}$ is the fluorescence polarization for bound 6-FAM-labeled DNA scaffold, and [T] is the concentration of $21 \mathrm{Q}$ or $21 \mathrm{Q}$ derivative.

Electrophoretic mobility shift assay of $\mathbf{Q}$ engagement. Electrophoretic mobility shift assays with the DNA scaffold for radioactive transcription assay were performed in reaction mixtures containing $(50 \mu \mathrm{l}): 0.1 \mu \mathrm{M} 21 \mathrm{Q}, 0.1 \mu \mathrm{M}$ E. coli RNAP$\sigma^{70}$ holoenzyme, $0.11 \mu \mathrm{M}$ DNA scaffold, $50 \mathrm{mM}$ Tris- $\mathrm{HCl}, \mathrm{pH} 8.0,0.1 \mathrm{M} \mathrm{KCl}, 10$ $\mathrm{mM} \mathrm{MgCl} 2,1 \mathrm{mM} \mathrm{DTT}$, and $5 \%$ glycerol. Reaction mixtures were incubated 10 min at $37^{\circ} \mathrm{C}$, supplemented with $1 \mathrm{mM}$ ATP, $1 \mathrm{mM}$ UTP, and $1 \mathrm{mM} \mathrm{GTP}$, and RNA synthesis was allowed to proceed for $10 \mathrm{~min}$ at $37^{\circ} \mathrm{C}$. Reaction mixtures were applied to 5\% polyacrylamide slab gels (29:1 acrylamide/bisacrylamide), electrophoresed in $90 \mathrm{mM}$ Tris-borate, $\mathrm{pH} \mathrm{8.0,} \mathrm{and} 0.2 \mathrm{mM}$ EDTA, stained with $4 \mathrm{~S}$ Red Plus Nucleic Acid Stain (Sangon Biotech, Inc.) according to the procedure of the manufacturer, and analyzed by ImageJ (https://imagej.nih.gov/ij/).

Fluorescence polarization assays of 21Q-FTH interaction. Equilibrium fluorescence polarization assays of 21Q-FTH interaction were performed analogously to fluorescence polarization assay of 21Q-QBE interaction, using $0-100 \mu \mathrm{M} 21 \mathrm{Q}$ or 21Q derivative and $0.1 \mu \mathrm{M} \mathrm{N}$-terminal 5-FAM-labeled peptide (TPEEKLLRAIFGEK, GenScript, Inc.)

Reporting summary. Further information on research design is available in the Nature Research Reporting Summary linked to this article.

\section{Data availability}

The data that support the findings of this study are available from the corresponding author upon reasonable request. The accession number for the cryo-EM density map reported in this paper is Electron Microscopy Data Bank: EMD-9852 [https://www. emdataresource.org/EMD-9852]. The accession numbers for the atomic coordinates reported in this paper are Protein Data Bank: 6JNX [https://www.rcsb.org/structure/ 6JNX] (21Q-engaged arrested complex) and 6JNY [https://www.rcsb.org/structure/ 6JNY] (21Q). The source data underlying Figs 1B, 3C-E, 4E, 4F, 5C, 5D, and Supplementary Fig. 1B are provided as a Source Data file.

Received: 11 April 2019 Accepted: 12 June 2019

Published online: 02 July 2019

\section{References}

1. Feklistov, A., Sharon, B. D., Darst, S. A. \& Gross, C. A. Bacterial sigma factors: a historical, structural, and genomic perspective. Annu. Rev. Microbiol. 68 , 357-376 (2014).

2. Zhang, Y. et al. Structural basis of transcription initiation. Science 338, 1076-1080 (2012).

3. Feklistov, A. \& Darst, S. A. Structural basis for promoter-10 element recognition by the bacterial RNA polymerase sigma subunit. Cell 147, 1257-1269 (2011).

4. Bae, B., Feklistov, A., Lass-Napiorkowska, A., Landick, R. \& Darst, S. A Structure of a bacterial RNA polymerase holoenzyme open promoter complex. eLife 4, e08504 (2015).

5. Feng, Y., Zhang, Y. \& Ebright, R. H. Structural basis of transcription activation. Science 352, 1330-1333 (2016).

6. Hubin, E. A. et al. Structure and function of the mycobacterial transcription initiation complex with the essential regulator RbpA. eLife 6, e22520 (2017).

7. Narayanan, A. et al. Cryo-EM structure of Escherichia coli sigma70 RNA polymerase and promoter DNA complex revealed a role of sigma non- conserved region during the open complex formation. J. Biol. Chem. 293, 7367-7375 (2018)

8. Zuo, Y. \& Steitz, T. A. Crystal structures of the E. coli transcription initiation complexes with a complete bubble. Mol. Cell 58, 534-540 (2015).

9. Roberts, J. W. et al. Antitermination by bacteriophage lambda Q protein. Cold Spring Harb. Symp. Quant. Biol. 63, 319-325 (1998).

10. Perdue, S. A. \& Roberts, J. W. Sigma70-dependent transcription pausing in Escherichia coli. J. Mol. Biol. 412, 782-792 (2011).

11. Strobel, E. J. \& Roberts, J. W. Two transcription pause elements underlie a sigma70-dependent pause cycle. Proc. Natl Acad. Sci. USA 112, E4374-E4380 (2015).

12. Bird, J. G., Strobel, E. J. \& Roberts, J. W. A universal transcription pause sequence is an element of initiation factor sigma70-dependent pausing. Nucleic Acids Res. 44, 6732-6740 (2016).

13. Guo, J. \& Roberts, J. W. DNA binding regions of $Q$ proteins of phages lambda and phi80. J. Bacteriol. 186, 3599-3608 (2004).

14. Nickels, B. E., Roberts, C. W., Sun, H., Roberts, J. W. \& Hochschild, A. The sigma70 subunit of RNA polymerase is contacted by the lambdaQ antiterminator during early elongation. Mol. Cell 10, 611-622 (2002).

15. Santangelo, T. J. \& Artsimovitch, I. Termination and antitermination: RNA polymerase runs a stop sign. Nat. Rev. Microbiol. 9, 319-329 (2011).

16. Guo, H. C., Kainz, M. \& Roberts, J. W. Characterization of the late-gene regulatory region of phage 21. J. Bacteriol. 173, 1554-1560 (1991).

17. Autour, A. et al. Fluorogenic RNA Mango aptamers for imaging small noncoding RNAs in mammalian cells. Nat. Commun. 9, 656 (2018).

18. Strobel, E. J. \& Roberts, J. W. Regulation of promoter-proximal transcription elongation: enhanced DNA scrunching drives lambdaQ antiterminatordependent escape from a sigma70-dependent pause. Nucleic Acids Res. 42, 5097-5108 (2014)

19. Campbell, E. A. et al. Crystal structure of Escherichia coli sigmaE with the cytoplasmic domain of its anti-sigma RseA. Mol. Cell 11, 1067-1078 (2003).

20. Campbell, E. A. et al. Structure of the bacterial RNA polymerase promoter specificity sigma subunit. Mol. Cell 9, 527-539 (2002).

21. Vorobiev, S. M. et al. Structure of the DNA-binding and RNA-polymerasebinding region of transcription antitermination factor lambdaQ. Structure 22, 488-495 (2014).

22. Kang, J. Y. et al. Structural basis of transcription arrest by coliphage HK022 Nun in an Escherichia coli RNA polymerase elongation complex. eLife 6, e25478 (2017).

23. Ring, B. Z., Yarnell, W. S. \& Roberts, J. W. Function of E. coli RNA polymerase sigma factor sigma70 in promoter-proximal pausing. Cell 86, 485-493 (1996).

24. Deighan, P., Diez, C. M., Leibman, M., Hochschild, A. \& Nickels, B. E. The bacteriophage lambda $\mathrm{Q}$ antiterminator protein contacts the beta-flap domain of RNA polymerase. Proc. Natl Acad. Sci. USA 105, 15305-15310 (2008).

25. Bar-Nahum, G. \& Nudler, E. Isolation and characterization of sigma(70)retaining transcription elongation complexes from Escherichia coli. Cell 106, 443-451 (2001).

26. Mukhopadhyay, J. et al. Translocation of sigma70 with RNA polymerase during transcription: fluorescence resonance energy transfer assay for movement relative to DNA. Cell 106, 453-463 (2001)

27. Kapanidis, A. N. et al. Retention of transcription initiation factor sigma70 in transcription elongation: single-molecule analysis. Mol. Cell 20, 347-356 (2005).

28. Kapanidis, A. N. et al. Initial transcription by RNA polymerase proceeds through a DNA-scrunching mechanism. Science 314, 1144-1147 (2006).

29. Revyakin, A., Liu, C., Ebright, R. H. \& Strick, T. R. Abortive initiation and productive initiation by RNA polymerase involve DNA scrunching. Science 314, 1139-1143 (2006)

30. Ray-Soni, A., Bellecourt, M. J. \& Landick, R. Mechanisms of bacterial transcription termination: all good things must end. Annu. Rev. Biochem. 85, 319-347 (2016).

31. Guo, X. et al. Structural basis for NusA stabilized transcriptional pausing. Mol. Cell 69, 816-827 (2018).

32. Kang, J. Y. et al. RNA polymerase accommodates a pause RNA hairpin by global conformational rearrangements that prolong pausing. Mol. Cell 69, 802-815 (2018).

33. Krupp, F. et al. Structural basis for the action of an all-purpose transcription anti-termination factor. Mol. Cell 74, 143-147 (2019).

34. Said, N. et al. Structural basis for lambdaN-dependent processive transcription antitermination. Nat. Microbiol. 2, 17062 (2017).

35. Engel, C. et al. Structural basis of RNA polymerase I transcription initiation. Cell 169, 120-131 (2017)

36. Igarashi, K. \& Ishihama, A. Bipartite functional map of the E. coli RNA polymerase alpha subunit: involvement of the $\mathrm{C}$-terminal region in transcription activation by cAMP-CRP. Cell 65, 1015-1022 (1991).

37. Svetlov, V. \& Artsimovitch, I. Purification of bacterial RNA polymerase: tools and protocols. Methods Mol. Biol. 1276, 13-29 (2015). 
38. Koulich, D. et al. Domain organization of Escherichia coli transcript cleavage factors GreA and GreB. J. Biol. Chem. 272, 7201-7210 (1997).

39. Otwinowski, Z. \& Minor, W. Processing of X-ray diffraction data collected in oscillation mode. Methods Enzymol. 276, 307-326 (1997).

40. Winn, M. D. et al. Overview of the CCP4 suite and current developments. Acta Crystallogr. D. Biol. Crystallogr. 67, 235-242 (2011).

41. Emsley, P. \& Cowtan, K. Coot: model-building tools for molecular graphics. Acta Crystallogr. D. Biol. Crystallogr. 60, 2126-2132 (2004).

42. Adams, P. D. et al. PHENIX: a comprehensive Python-based system for macromolecular structure solution. Acta Crystallogr. D Biol. Crystallogr. 66, 213-221 (2010).

43. Mastronarde, D. N. Automated electron microscope tomography using robust prediction of specimen movements. J. Struct. Biol. 152, 36-51 (2005).

44. Zheng, S. Q. et al. MotionCor2: anisotropic correction of beam-induced motion for improved cryo-electron microscopy. Nat. Methods 14, 331-332 (2017).

45. Rohou, A. \& Grigorieff, N. CTFFIND4: fast and accurate defocus estimation from electron micrographs. J. Struct. Biol. 192, 216-221 (2015)

46. Scheres, S. H. RELION: implementation of a Bayesian approach to cryo-EM structure determination. J. Struct. Biol. 180, 519-530 (2012).

47. Pettersen, E. F. et al. UCSF Chimera-a visualization system for exploratory research and analysis. J. Comput. Chem. 25, 1605-1612 (2004).

\section{Acknowledgements}

We thank Li Huang at the Center of Cryo Electron Microscopy in Zhejiang University School of Medicine for help with cryo-EM sample preparation. We thank for the technical support by the Core Facilities, Zhejiang University School of Medicine. This work was funded by National Key R\&D Program of China (2018YFA0507800 to Y.F., 2017YFA0504803 to X.Z., and 2018YFA0507700 to X.Z.) and the Fundamental Research Funds for the Central Universities (2018XZZX001-13 to X.Z.).

\section{Author contributions}

J.S., X.G., T.T., Z.Y., B.G., A.W., L.Y., and S.C. performed the experiments. X.Z., Y.Z., and Y.F. supervised the experiments. All authors contributed to the analysis of the data and the interpretation of the results. Y.F. wrote the manuscript with contributions from the other authors.

\section{Additional information}

Supplementary Information accompanies this paper at https://doi.org/10.1038/s41467019-10958-8.

Competing interests: The authors declare no competing interests.

Reprints and permission information is available online at http://npg.nature.com/ reprintsandpermissions/

Peer Review Information: Nature Communications thanks Seth Darst and Katsuhiko Murakami for their contribution to the peer review of this work. Peer reviewer reports are available.

Publisher's note: Springer Nature remains neutral with regard to jurisdictional claims in published maps and institutional affiliations.

(c) (i) Open Access This article is licensed under a Creative Commons Attribution 4.0 International License, which permits use, sharing, adaptation, distribution and reproduction in any medium or format, as long as you give appropriate credit to the original author(s) and the source, provide a link to the Creative Commons license, and indicate if changes were made. The images or other third party material in this article are included in the article's Creative Commons license, unless indicated otherwise in a credit line to the material. If material is not included in the article's Creative Commons license and your intended use is not permitted by statutory regulation or exceeds the permitted use, you will need to obtain permission directly from the copyright holder. To view a copy of this license, visit http://creativecommons.org/ licenses/by/4.0/.

(C) The Author(s) 2019 